\title{
Effect of enzymatic hydrolysis on some physicochemical properties of root and tuber granular starches
}

\author{
Efeito da hidrólise enzimática sobre algumas propriedades físico-químicas de amidos de raízes e tubérculos
}

Thaís de Souza ROCHA ${ }^{1}$, Ana Paula de Almeida CARNEIRO ${ }^{1}$, Celia Maria Landi FRANCO ${ }^{1 \star}$

\begin{abstract}
Enzymatic hydrolysis of granular starch is an important tool to provide information about granule structure. Cassava, sweet potato, Peruvian carrot, and potato starches were hydrolyzed by bacterial $\alpha$-amylase at $37^{\circ} \mathrm{C}$ for 48 hours, and the physicochemical properties of the residues from hydrolysis were determined. Cassava starch was the most susceptible to enzyme displaying $20.9 \%$ of hydrolysis, whereas potato starch was the most resistant with 5.9\%. The granule average size varied from 10.8 to $23.4 \mu \mathrm{m}$ for Peruvian carrot and potato starches, respectively. With the use of SEM, a smooth granule surface was observed for all native starches. Cassava and sweet potato starches displayed an A-type X-ray diffraction pattern, while Peruvian carrot and potato starches showed a B-type pattern. After hydrolysis, cassava, sweet potato, and Peruvian carrot starches showed some well degraded granules, whereas potato starch presented a slight sign of degradation. The amylose content of the starches decreased with hydrolysis for cassava, sweet potato, and Peruvian carrot starches and was kept unchanged for the potato starch. As expected, intrinsic viscosity and pasting properties decreased for all hydrolyzed starches. There is no difference between thermal properties of native and hydrolyzed starches. These results suggested that hydrolysis occurred in amorphous and crystalline areas of the granules. The B type diffraction pattern in conjunction with the big granule size of the potato starch may have contributed to the greatest resistance of this starch to hydrolysis.
\end{abstract}

Keywords: $\alpha$-amylase; granular starch; structure.

\begin{abstract}
Resumo
A hidrólise enzimática do amido pode fornecer informações importantes sobre sua estrutura granular. Amidos de mandioca, batata-doce, mandioquinha-salsa e batata foram hidrolisados por $\alpha$-amilase bacteriana a $37^{\circ} \mathrm{C}$ durante 48 horas, e algumas propriedades físico-químicas dos resíduos da hidrólise foram determinadas. O amido de mandioca foi o mais suscetível à enzima com $20,9 \%$ de hidrólise, enquanto o amido de batata foi o mais resistente com 5,9\%. O tamanho médio dos grânulos variou de 10,8 a 23,4 $\mu$ m para os amidos de mandioquinha-salsa e batata, respectivamente. Amidos de mandioca e batata-doce apresentaram um padrão de difração de raio-X tipo A, enquanto os amidos de mandioquinha-salsa e batata mostraram padrão tipo B. Todos os amidos nativos mostraram superfície granular lisa e, após hidrólise, os amidos de mandioca, batata-doce e mandioquinha-salsa mostraram alguns grânulos bastante degradados, enquanto o amido de batata apresentou sutil sinal de degradação. O teor de amilose dos amidos diminuiu com a hidrólise para os amidos de mandioca, batata-doce e mandioquinha-salsa, permanecendo inalterado para o amido de batata. Como esperado, a viscosidade intrínseca e as propriedades de pasta diminuíram para todos os amidos hidrolisados. Não houve diferença significativa entre as propriedades térmicas dos amidos nativos e hidrolisados. Estes resultados sugeriram que a hidrólise ocorreu nas áreas cristalinas e amorfas dos grânulos. O padrão de difração do tipo B e o grande tamanho dos grânulos do amido de batata podem ter contribuído para a maior resistência deste amido à hidrólise.

Palavras-chave: $\alpha$-amilase; amido granular; estrutura.
\end{abstract}

\section{Introduction}

Enzymatic hydrolysis of granular starch has been used as an effective tool to better understand the starch granule structure.

Starch granule is organized in amorphous areas and in regions of higher and lower cristallinity, and the transition between them is gradual. The crystalline area is constituted of linear fractions of amylopectin, whereas branch points and amylose are the main components of amorphous areas (OATES, 1997; JANE, 2006).

Differences in the enzymatic susceptibilities of starches have been attributed to the interactions of many factors such as starch source, granule size, extension of association between starch components, rate of amylose and amylopectin, crystallinity, polymorphic type (A, B, C), amylose-lipid complex, type of enzyme, and hydrolysis conditions (concentration, $\mathrm{pH}$, temperature) (OATES, 1997; COLONNA; BULÉON; LEMANE, 1988; HOOVER; ZHOU, 2003; LI et al., 2004; TESTER; QI; KARKALAS, 2006).

Starches that naturally present a porous surface, such as corn starch, are degraded easier than those with a smooth surface such as cassava starch (FRANCO; CIACCO; TAVARES, 1988, FRANCO; CIACCO, 1992). Granules with lower diameter are more susceptible to enzymes than those of higher

Recebido para publicação em 15/10/2008

Aceito para publicação em 20/6/2009 (003853)

${ }^{1}$ Departamento de Engenharia e Tecnologia de Alimentos, Instituto de Biociências, Letras e Ciências Exatas, Universidade Estadual Paulista - UNESP, Rua Cristóvão Colombo, Jd. Nazareth, CEP 15054-000, CP 2265, São José do Rio Preto - SP, Brasil, E-mail: celia@ibilce.unesp.br

${ }^{*}$ A quem a correspondência deve ser enviada 
diameter (FRANCO; CIACCO, 1992; FRANCO; CIACCO; TAVARES, 1998; YONEMOTO; CALORI-DOMINGUES; FRANCO, 2007) due to their higher surface area (TESTER; QI; KARKALAS, 2006). Franco and Ciacco (1992) observed that the enzymatic attack on the large granules of cassava and corn starches $(>16 \mu \mathrm{m})$ was characterized by considerable corrosion of granule surface, mainly in the radial direction. For small granules, the enzymatic action was characterized, mainly by surface erosion with partial or total solubilisation of the granules.

Starches with different polymorphic patterns (A, B, or C) have shown different susceptibilities to enzymatic hydrolysis. Hoover and Zhou (2003) reported that legume granular starches (C-type) are more susceptible to pancreatic a-amylase than granular starches of potato or corn with high amylose (B-type), but less susceptible than cereal or cassava granular starches (A- type).

During enzymatic hydrolysis, some regions of granules are more attacked than others. Those more susceptible areas are the less organized amorphous rings, whereas the crystalline lamella offers higher resistance to enzymatic erosion (OATES, 1997). However, Colonna, Buléon and Lemane (1988) suggested that $\alpha$-amylase can simultaneously attack the crystalline and amorphous areas of starch granule, whereas Lauro et al. (1999) reported that at the initial stage of hydrolysis of barley starch, both amorphous and crystalline areas were equally attacked by $a$-amylase. Nevertheless, the crystallinity and gelatinization enthalpy decreased after a long period of hydrolysis suggesting that an extensive hydrolysis effectively destroys and dissolves the crystalline areas of the granule (HOOVER; ZHOU, 2003).

The enzymatic hydrolysis of granular starch also causes significant changes in the functional properties of starches such as gelatinization temperatures, gel formation, and paste viscosity which are very important to define the industrial uses of starches. Starches hydrolyzed by enzymes have their molecular weight reduced and show reduction of paste viscosities and swelling power (NODA et al, 2004).

Commercial starches are obtained from seeds (corn, waxy corn, high amylose corn, wheat, and rice) and from tubers and roots, particularly potato, sweet potato, and cassava (WHISTLER; BEMILLER, 1997). Other starches such as that of Peruvian carrot have less commercial applications, and publications about this starch are fewer in relation to those of corn starch. Although extensive studies have been carried out in recent years, the available information on root and tuber starch granule structure and the action of amylases on these starches still deserves attention.

The purpose of this work was to investigate the enzymatic susceptibility of different root and tuber starches (cassava, sweet potato, Peruvian carrot, and potato starches) to bacterial $\alpha$-amylase action and to evaluate some physicochemical characteristics of hydrolyzed residues to obtain more information about starch structure and functionality.

\section{Materials and methods}

\subsection{Material}

Cassava (Manihot esculenta), sweet potato (Ipomoea batatas), Peruvian carrot (Arracacia xanthorrhiza), and potato (Solanum tuberosum) roots and tubers were cultivated in São José do Rio Preto - SP, Brazil. Bacterial $\alpha$-amylase (A6380), with declared activity of 2150 units. $\mathrm{mg}^{-1}$ solid was obtained from Sigma Chemical CO., USA.

\subsection{Isolation of starches}

Starches were isolated as described by Peroni, Rocha and Franco (2006).

\subsection{Chemical composition}

The starches were analyzed for moisture, ash, protein, and lipid contents according to the American Association of Cereal Chemists, (AMERICAN ASSOCIATION OF CEREAL CHEMISTS, 2000).

\subsection{Granule size distribution}

The granule size distribution of the different starches was performed using an image analyzer system "Image-pro-plus" (Media Cybernetics) attached to a light microscope as described by Peroni, Rocha and Franco (2006). The parameters evaluated were shape and the largest diameter $(\mu \mathrm{m})$. Three slides for each sample were prepared and a hundred granules were randomly chosen and measured per slide.

\subsection{Cristallinity of the starches}

The pattern of crystallinity of starches was determined using $\mathrm{X}$-rays in a RINT2000 Wide Angle Goniometer unit with copper radiation, line $\mathrm{K}, \mathrm{L}=1,542 \AA$. The scanning speed was $1^{\circ} \mathrm{min}^{-1}$ at $50 \mathrm{kV}$ and $100 \mathrm{~mA}$.

\subsection{Enzymatic hydrolysis}

The starches were hydrolyzed with bacterial $\alpha$-amylase, in duplicate, according to Franco and Ciacco (1992) with modifications. The starches $(15 \%, \mathrm{w} / \mathrm{v})$ were dispersed in phosphate buffer $(0.2 \mathrm{M} \mathrm{pH} 6.0)$ with $3 \mathrm{~mL}$ of bacterial $\alpha$-amylase solution $(0.2 \% \mathrm{w} / \mathrm{v})$. An aliquot of $1 \mathrm{~mL}$ of sodium azide solution $(10 \% \mathrm{w} / \mathrm{v})$ was added to avoid microbial growth. The starch dispersions were incubated for 48 hours at $37^{\circ} \mathrm{C}$ in an orbital shaker. After solids decant, aliquots of the supernatant were removed at $6,9,24,30$, and 48 hours, and the amount of reducing sugars was determined (SOMOGYI, 1945).

After 48 hours of incubation, the enzyme in the dispersion was inactivated by adding $\mathrm{HCl}(0.1 \mathrm{~N})$ to reach $\mathrm{pH} 3.0$ followed by stirring for 15 minutes, neutralization with $\mathrm{NaOH}(0.1 \mathrm{~N})$, and centrifugation at $2100 \mathrm{~g}$ for 20 minutes. The hydrolysis residues were washed with distilled water and ethanol, recovered by filtration, and dried in an air circulation oven at $40{ }^{\circ} \mathrm{C}$. The 
hydrolysis percentage was calculated in relation to the dry basis (db) starch weight by Equation 1:

Percentage of hydrolysis $=\frac{100 \times\left[\begin{array}{l}\text { weight of starch }(\mathrm{g}, \mathrm{db})- \\ \text { weight of hydrolyzed starch }(\mathrm{g}, \mathrm{db})\end{array}\right]}{\text { weight of starch }(\mathrm{g}, \mathrm{db})}$

\subsection{Scanning Electron Microscopy (SEM)}

An aliquot of sample, previously dehydrated with ethanol was placed on a metal plate, previously covered with a carbon double sided adhesive tape, submitted to a $20 \mathrm{~nm}$ gold layer application, and observed with a scanning electron microscope, model DSM 960 ZEISS - "Digital Scanning Microscope".

\subsection{Amylose content}

The starch samples were defatted by dispersing starch in 90\% DMSO solution which was boiled and stirred for one hour (FRANCO et al., 2002). The iodine affinities of defatted whole starch were determined according to Kasemsuwan et al. (1995) using a potentiometric autotitrator (716SM Titrino, Brinkmann Instrument, Westbury, NY). The amylose contents were calculated dividing the iodine affinity of starch by $20.0 \%$ (TAKEDA; HIZUKURI, 1987).

\subsection{Intrinsic viscosity}

The starch solutions were prepared as proposed by Lansky, Kooi and Schoch (1949), and the intrinsic viscosity was analyzed according to Leach (1963). A capillary viscosimeter (CannonFenske, number 50, Fisher Scientific, USA) was used and maintained at $35^{\circ} \mathrm{C}$ by using a thermostated bath.

\subsection{Thermal properties}

The gelatinization properties of starch samples were determined by using a differential scanning calorimeter (DSCPyris 1, Perkin Elmer, Norwalk, CT) (FRANCO et al, 2002 ). The heating rate used was $5^{\circ} \mathrm{C} \mathrm{min}^{-1}$.

\subsection{Pasting properties}

The pasting properties of starches were obtained using a Rapid Visco Analyzer (RVA-4, Newport Scientific, Australia) according to Franco et al., (2002).

\subsection{Statistical analysis}

All samples were analyzed in duplicate or in triplicate. The statistical analysis was performed using the data analysis tools of Statistics for Windows (v. 5.0, Statsoft, Tulsa, OK). The analysis of variance was conducted using Tukey's studentized range test at the $5 \%$ of significance.

\section{Results and discussion}

\subsection{Chemical composition}

As expected for root and tuber starches, all samples displayed low contents of ash, protein, and lipid $(<0.5 \%$, Table 1$)$ indicating that the starches were pure enough to be used.

\subsection{Enzymatic hydrolysis}

The cassava was the most susceptible to hydrolysis followed by sweet potato and Peruvian carrot starches (Figure 1), which presented similar behavior during hydrolysis, mainly after 15 hours of treatment. The potato starch was the most resistant to enzyme action and it practically did not suffer degradation under the conditions of this experiment. The percentage of hydrolysis, calculated according to Equation 1 described in the material and methods section of this work, was of $20.9 \%$ for the cassava starch, whereas the potato presented 5.9\% of hydrolysis (Table 2). Sweet potato and Peruvian carrot starches showed hydrolysis percentages of 15.5 , and $13.2 \%$, respectively. According to Rickard, Asaoka and Blanshard (1991), for starches from non-cereal sources, the cassava starch is the most susceptible to $a$-amylase, and the potato starch, the most resistant. It is well known that cassava and sweet potato starches display an A-type X-ray diffraction pattern, whereas potato starch shows B-type pattern (COTTRELL et al., 1995; JANE et al., 1999; MCPHERSON; JANE, 1999; HOOVER, 2001; SRICHUWONG et al., 2005). We also found

Table 1. Chemical composition of granular starches*.

\begin{tabular}{lccc}
\hline \multicolumn{1}{c}{ Starch } & Ash & Protein & Lipid \\
\hline Cassava & $0.19 \pm 0.01$ & $0.18 \pm 0.03$ & $0.12 \pm 0.03$ \\
Sweet potato & $0.21 \pm 0.01$ & $0.14 \pm 0.03$ & $0.14 \pm 0.01$ \\
Peruvian carrot & $0.18 \pm 0.03$ & $0.12 \pm 0.01$ & $0.13 \pm 0.03$ \\
Potato & $0.15 \pm 0.02$ & $0.12 \pm 0.01$ & $0.10 \pm 0.02$ \\
\hline
\end{tabular}

* Results expressed in dry basis; mean values of three replicates per sample.

Table 2. Percentage of hydrolysis of starches submitted to $a$-amylase action for 48 hours.

\begin{tabular}{lc}
\hline Starch & \% Hydrolysis * \\
\hline Cassava & $20.9^{\mathrm{a}}$ \\
Sweet potato & $15.5^{\mathrm{b}}$ \\
Peruvian carrot & $13.2^{\mathrm{c}}$ \\
Potato & $5.9^{\mathrm{d}}$ \\
\hline
\end{tabular}

${ }^{*}$ Percentage of hydrolysis $=100 \times$ [weight of starch $(\mathrm{g})$ - weight of hydrolyzed starch $(\mathrm{g}) /$ weight of starch $(\mathrm{g})]$; and values followed by the same letter are not significantly different $(P<0.05)$.
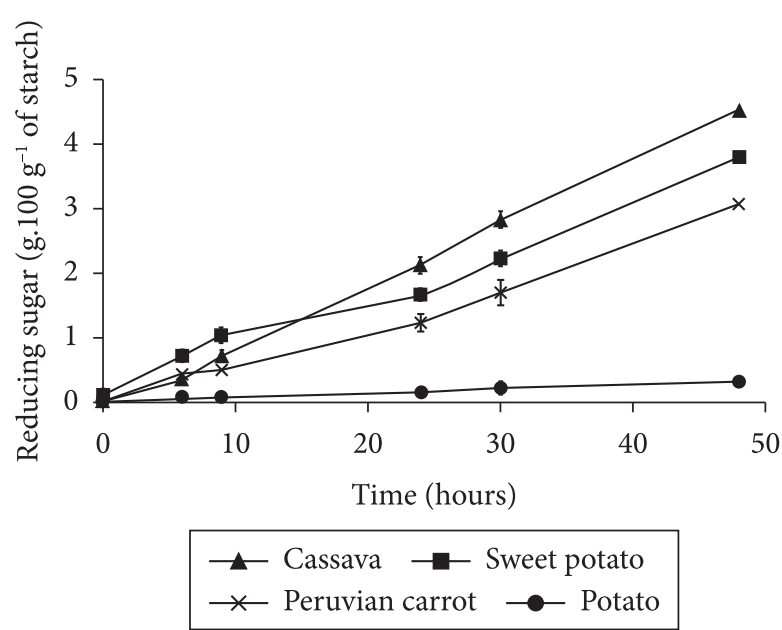

Figure 1. Amount of reducing sugar produced during the hydrolysis of different starches with bacterial $\alpha$-amylase, as a function of time. 
an A-type X-ray diffraction pattern for cassava and sweet potato starches (Figure $2 \mathrm{a}, \mathrm{b}$ ) while Peruvian carrot and potato starches showed a B-type pattern (Figure $2 \mathrm{c}, \mathrm{d}$ ). In a previous study, Rocha, Demiate and Franco (2008) reported a B-type pattern for Peruvian carrot starch which was also reported by Santacruz et al. (2003). Starches with A-type polymorphism are more susceptible to amylases action than starches with B-type polymorphism (JANE, 2006; HOOVER; ZHOU, 2003; GÉRARD et al., 2001). In the A-type starches, $A$ and $B_{1}$ short chains in the crystalline structure are less stable and more susceptible to rearrangements, whereas B-type starches present higher proportions of long B chains, which extend for two or more clusters and stabilize the internal structure of granules becoming more resistant to enzymatic action (JANE, 2006).

\subsection{Shape and size distribution of granules}

Starch granules from different sources showed distinct shape and size. Cassava and Peruvian carrot starch granules displayed round shapes, whereas the sweet potato starch showed granules with round and polygonal shapes, and potato starch granules were elliptical (Figure 3). Cassava and sweet potato starches displayed granules with similar average size (15.6

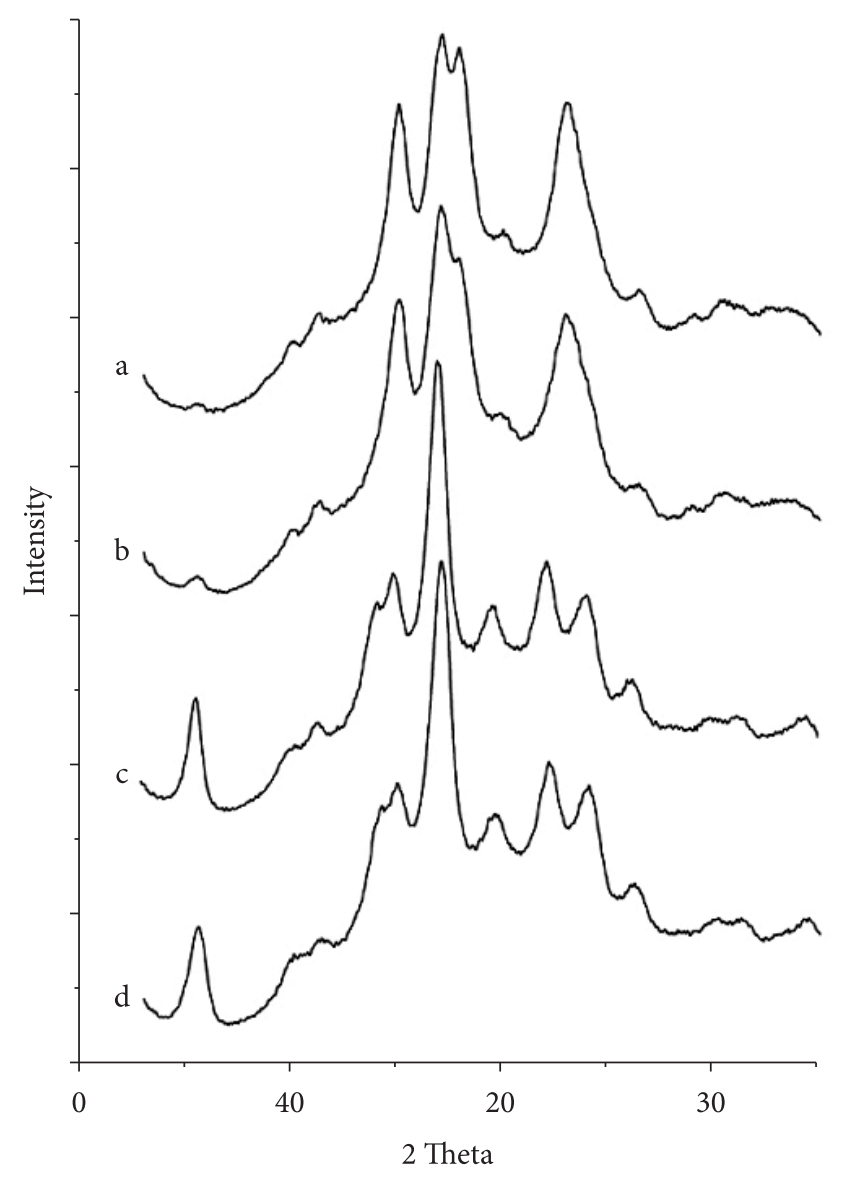

Figure 2. X-ray diffraction pattern of native starches: a) cassava; b) sweet potato; c) Peruvian carrot; and d) potato. and $13.4 \mu \mathrm{m}$, respectively) presenting more than $70 \%$ of the granules with diameters between 10.1 and $20.0 \mu \mathrm{m}$, agreeing with Peroni, Rocha and Franco (2006)'s findings. A lower granule average diameter for the Peruvian carrot $(10.8 \mu \mathrm{m})$ was observed, whereas the potato starch displayed an average diameter of $23.4 \mu \mathrm{m}$ and proximately $50 \%$ of the granules with diameter higher than $20.0 \mu \mathrm{m}$ (Table 3). It is possible that, among the B- type diffraction pattern presented by the potato starch (Figure 2d), its highest granule size has also contributed for its highest resistance to hydrolysis. The enzymatic digestion pattern of starch granules of a smaller size differs from those of a larger size (LINDEBOOM; CHANG; TYLER, 2004), and the small ones are hydrolyzed faster than the large ones (OATES, 1997; FRANCO; CIACCO, 1992; YONEMOTO; CALORIDOMINGUES; FRANCO, 2007). According to Tester, Qi and Karkalas (2006), the enzymatic hydrolysis of granular starch involves enzymes in solution acting on a solid substrate and then, the surface area accessible to enzymes becomes an important kinetic parameter.

A smooth granule surface of all native starches was observed using scanning electron microscopy, (Figure 4). After hydrolysis, cassava, sweet potato and Peruvian carrot starches showed some granules degraded on their external part (Figures $4 \mathrm{~b}$, d, and $\mathrm{f})$, indicating that hydrolysis occurred by exocorrosion, and it was not uniform for all granules of each starch, in which some regions were much more susceptible to enzymes than others, probably due to the structural characteristics of each starch. According to Oates (1997), enzymes cause alteration on the granule surface and degrade the external part by exocorrosion. When endocorrosion occurs, the internal part of the granule is corroded forming small pores through which enzymes penetrate into the granule. In this study, it was not possible to observe any endocorrosion of the starches after hydrolysis, except for the Peruvian carrot starch that showed some granules with internal degradation (Figure $4 \mathrm{f} \downarrow$ ). The hydrolyzed potato starch granules showed only a slight signal of exocorrosion
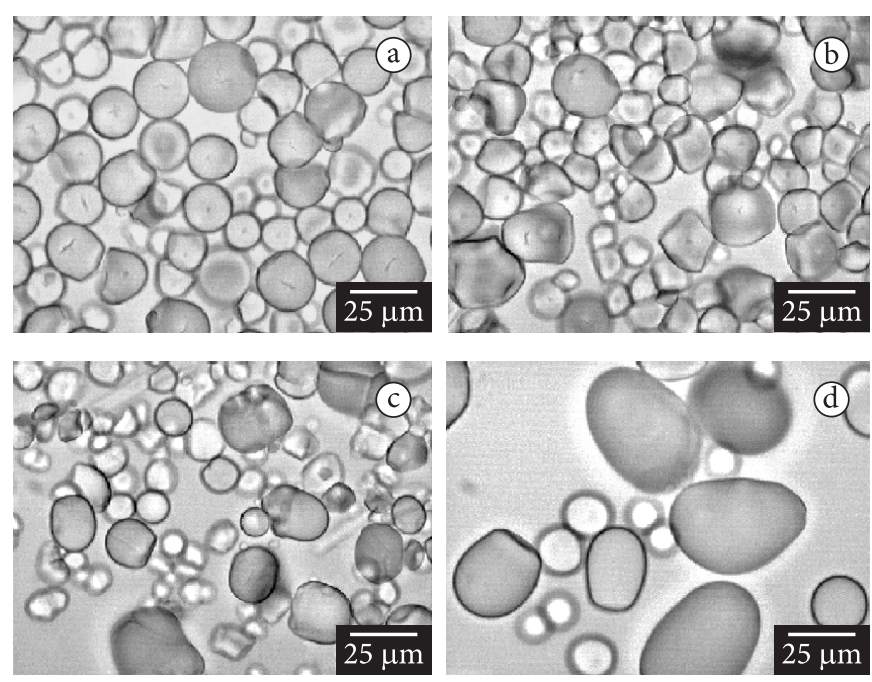

Figure 3. Photomicrographs of native starches observed in an optical microscope: a) cassava; b) sweet potato; c) Peruvian carrot; and d) potato. 
Table 3. Overall and average sizes and granular size distribution of starches.

\begin{tabular}{|c|c|c|c|c|c|}
\hline \multirow[t]{2}{*}{ Starch } & \multirow[t]{2}{*}{ Overall size $(\mu \mathrm{m})$} & \multirow[t]{2}{*}{ Average size $(\mu \mathrm{m})$} & \multicolumn{2}{|c|}{ Size distribution } & \multirow[t]{2}{*}{ Shape } \\
\hline & & & Size $(\mu \mathrm{m})$ & $\%$ & \\
\hline \multirow[t]{2}{*}{ Cassava } & $7.3-23.7$ & $15.6^{\mathrm{b}}$ & $5.0-10.0$ & 8.4 & Round \\
\hline & & & $>20.0$ & 19.6 & \\
\hline \multirow[t]{2}{*}{ Sweet potato } & $7.2-28.3$ & $13.4^{\mathrm{c}}$ & $5.0-10.0$ & 21.4 & Round and \\
\hline & & & $10.1-20.0$ & 70.8 & polygonal \\
\hline \multirow[t]{3}{*}{ Peruvian carrot } & $1.4-30.2$ & $10.8^{\mathrm{d}}$ & $1.0-5.0$ & 12.7 & Round \\
\hline & & & $5.1-15.0$ & 67.6 & \\
\hline & & & $>15.0$ & 19.7 & \\
\hline \multirow[t]{2}{*}{ Potato } & $6.7-66.0$ & $23.4^{\mathrm{a}}$ & $5.0-20.0$ & 51.4 & Elliptical \\
\hline & & & $20.1-30.0$ & 25.3 & \\
\hline
\end{tabular}

* Values followed by the same letter are not significantly different $(P<0.05)$.
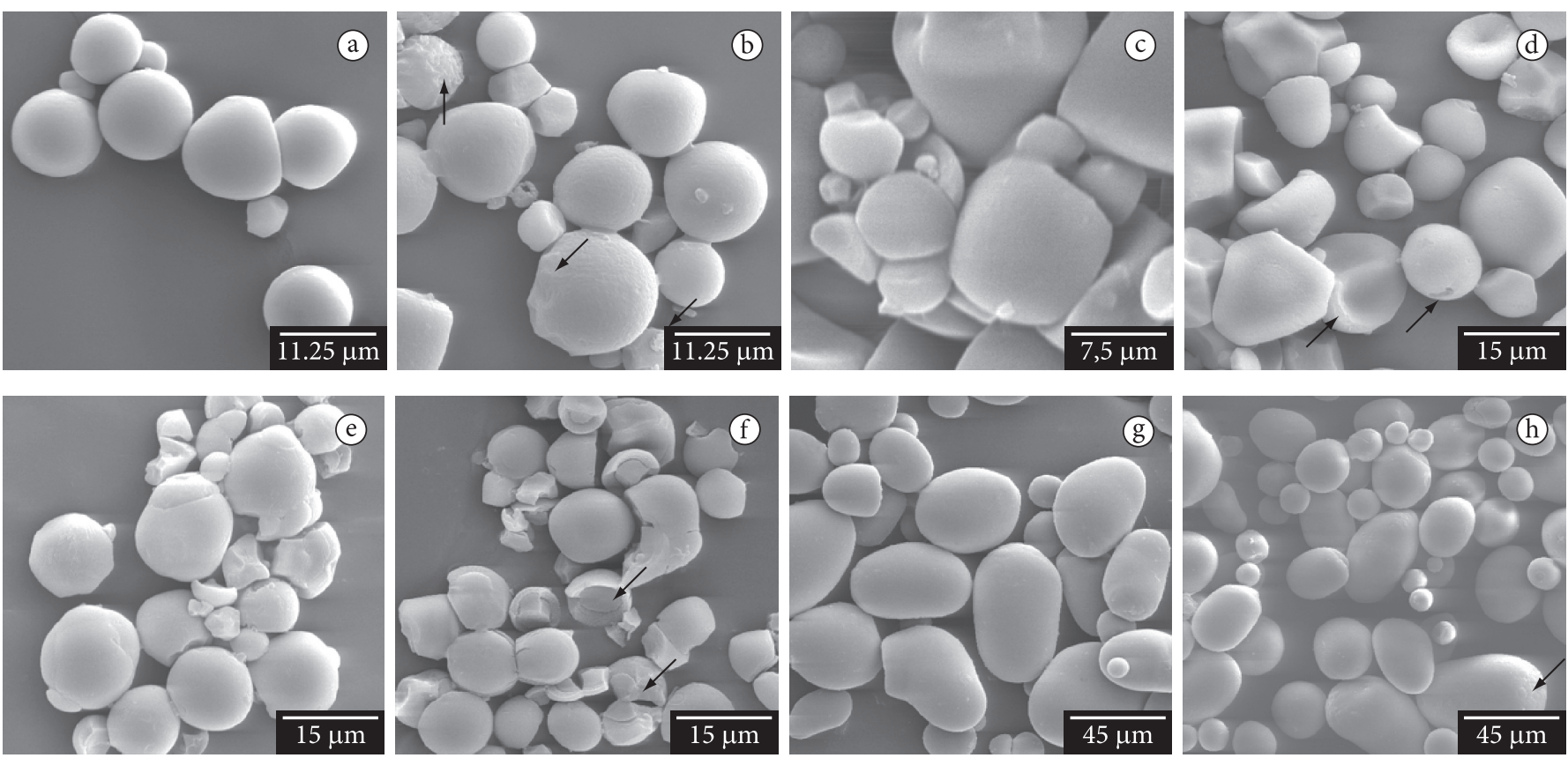

Figure 4. Photomicrographs of starches observed in SEM before (a, c, e, and g) and after hydrolysis (b, $d$, $f$, and h) with bacterial $\alpha$-amylase: (a and b) cassava; (c and d) sweet potato; (e and f): Peruvian carrot; (g and h): potato.

(Figure $4 \mathrm{~h} \downarrow$ ). Gallant, Mercier and Guilbot (1972), who also reported higher resistance of the potato starch to enzymatic action, observed by SEM that the external part of the granules were kept intact after hydrolysis, and when the attack reached the internal regions of the granules, the hydrolysis occurred faster. In our experiments, no degradation signal in internal areas of the potato starch granules was observed.

\subsection{Amylose content}

The amylose content affects gelatinization and retrogradation properties, swelling power, and enzymatic susceptibility of starches (GÉRARD et al., 2001; YOU; IZYDORCZYK, 2002).
There was no significant difference between the amylose contents of cassava and sweet potato starches, which showed values around of $20 \%$. The Peruvian carrot starch displayed amylose content of $18.7 \%$, whereas the potato presented the highest amylose content (28.9\%). Most starches contain 20-30\% amylose depending on the botanical source. Hoover (2001) found values varying from 18.6 to $25.6 \%$ for the cassava starch depending on the plant variety. Also, according to Moorthy (2001), the sweet potato starch was found to have an amylose content of $20-25 \%$ depending on the variety, and Rocha, Demiate and Franco (2008) observed values of 21.7 and $17.8 \%$ for starches from two varieties of Peruvian carrot. Cottrell et al. 
(1995) reported amylose contents varying from 24.4 to $27.3 \%$ for four potato cultivars, whereas Ganga and Corke (1999) showed values varying from 20.1 to $35.1 \%$ for twenty-four potato genotypes.

The enzymatic hydrolysis caused a decrease in the amylose contents of all starches, except for the potato starch, which kept the amylose content unchanged (Table 4).

The higher the enzymatic susceptibility of the starches to $a$-amylase, the higher the reduction of amylose content of these starches. Therefore, it was possible to observe that $18.6 \%$ of cassava amylose was degraded by enzyme, whereas 7.2 and $7.5 \%$ of sweet potato and Peruvian carrot amylose molecules, respectively, suffered degradation during hydrolysis. Zhang and Oates (1999) observed that the molecular weight of sweet potato amylose decreased after the treatment of the starch with bacterial $\alpha$-amylase.

It is not clear whether amylose or amylopectin fraction is more affected by enzymatic hydrolysis. Yamada et al. (1995) reported that amylose could exist in the starch granules independently of the amylopectin suggesting that these linear molecules prevail in the amorphous areas of granules. Nevertheless, Jane (2006) reported that amylose, which is part of amorphous areas, is concentrated mainly in the granule periphery improving the interaction between amylose and amylopectin in those regions. Amylose and amylopectin molecules strongly associated in the periphery of the granules would be less susceptible to enzymatic attack justifying why starches with high proportions of amylose are more resistant to enzymes.

\subsection{Intrinsic viscosity}

Enzymatic hydrolysis caused a reduction of intrinsic viscosities of 9.8, 8.7, 4.9, and 1.3\% for cassava, sweet potato, Peruvian carrot, and potato starches, respectively (Table 4). This reduction in the intrinsic viscosities of hydrolyzed starches in relation to the original starches can be explained by the enzyme action on the amylose and amylopectin molecules. These results confirmed the highest enzymatic susceptibility for the cassava starch and the lowest one for the potato starch. According to

Table 4. Amylose content ${ }^{*}$ and intrinsic viscosity of starches before and after hydrolysis with bacterial $\alpha$-amylase ${ }^{\star *}$.

\begin{tabular}{lccccc}
\hline \multirow{2}{*}{ Starch } & \multicolumn{2}{c}{ Amylose content (\%) } & & \multicolumn{2}{c}{ Intrinsic viscosity } \\
\cline { 2 - 3 } \cline { 5 - 6 } & $\begin{array}{c}\text { Before } \\
\text { hydrolysis }\end{array}$ & $\begin{array}{c}\text { After } \\
\text { hydrolysis }\end{array}$ & & $\begin{array}{c}\text { Before } \\
\text { hydrolysis }\end{array}$ & $\begin{array}{c}\text { After } \\
\text { hydrolysis }\end{array}$ \\
\hline Cassava & $19.9^{\mathrm{bc}}$ & $16.2^{\mathrm{e}}$ & & $2.44^{\mathrm{a}}$ & $2.20^{\mathrm{b}}$ \\
Sweet potato & $20.7^{\mathrm{b}}$ & $19.2^{\mathrm{cd}}$ & & $1.83^{\mathrm{c}}$ & $1.67^{\mathrm{d}}$ \\
Peruvian carrot & $18.7^{\mathrm{d}}$ & $17.3^{\mathrm{e}}$ & & $2.43^{\mathrm{a}}$ & $2.31^{\mathrm{b}}$ \\
Potato & $28.9^{\mathrm{a}}$ & $28.8^{\mathrm{a}}$ & & $2.28^{\mathrm{b}}$ & $2.25^{\mathrm{b}}$ \\
\hline
\end{tabular}

"Iodine affinity (IA) for pure amylose was assigned as 20\% (TAKEDA; HIZUKURI, 1987); Amylose content = IA/0.20; "Each value represents average of two replicates for amylose content and three replicates for intrinsic viscosity. Values followed by the same letter, for each analysis, are not significantly different $(P<0.05)$.
Leach and Schoch (1961), intrinsic viscosity of a-amylase in vitro hydrolysis residues was slightly lower than that of the original starch, which can also be observed in this study, in which the maximum decrease observed for the cassava starch did not reach $10 \%$.

\subsection{Pasting properties}

Native starches displayed a typical viscosity pattern, an increase of viscosity up to a peak followed by a drop of viscosity under agitation and heating (Figure 5). The peak viscosity of hydrolyzed starches dropped; such reduction was larger for the starches that were more degraded by enzyme. Like what was observed for intrinsic viscosity, the reduction of peak viscosity of hydrolyzed starches was expected since the $\alpha$-amylase acts on the starch molecules breaking $\alpha-(1-4)$ linkages and providing dextrin which presents a lower swelling during gelatinization. Since the peak viscosity is related mainly to the swelling of amylopectin molecules (TESTER; QI; KARKALAS, 2006), these results suggest that besides some amylose molecules, some amylopectin molecules were also degraded during the hydrolysis of cassava, sweet potato, and Peruvian carrot starches. These starches did not present any viscosity during the constant heating and cooling cycles of pastes.

\subsection{Thermal properties}

The gelatinization temperatures and enthalpy changes of native starches are shown in Table 5, which displays values close to those found in the literature (HOOVER, 2001; ROCHA; DEMIATE; FRANCO, 2008; GANGA; CORKE, 1999). After statistical analysis, it was observed that the gelatinization temperatures $\left(T_{o}, T_{p}, T_{c}\right)$ and $\Delta H$ for all starches remained unchanged after hydrolysis, except for the peak temperature of the hydrolyzed cassava starch that was lightly lower when compared with the native cassava starch. These results suggested that either the enzyme attacked simultaneously the crystalline and amorphous areas of the granules of cassava, sweet potato and Peruvian carrot starches, or the hydrolysis was not enough to alter the amorphous and organized areas of these granules because both starches that suffered hydrolysis and the potato starch did not have their thermal properties changed. From the amylose content, intrinsic viscosity, and pasting property analysis, it was observed that some amylose and amylopectin molecules of cassava, sweet potato, and Peruvian carrot starches were degraded by enzyme, and thus it is probable that for these starches there was degradation of amorphous and crystalline areas.

Zhou, Hoover and Liu (2004) observed slight increase of the gelatinization temperatures and decrease in $\Delta \mathrm{H}$ when legume starches were treated with pancreatic $\alpha$-amylase. The decrease in the $\Delta \mathrm{H}$ of starches after hydrolysis suggests that $\alpha$-amylase is able to hydrolyze crystallites from branch chains of amylopectin and retrograded amylose (formed by hydrolyzed amylose chains) (ZHOU, HOOVER, LIU; 2004). In our experiments, the extent of hydrolysis was not enough to cause these effects. 

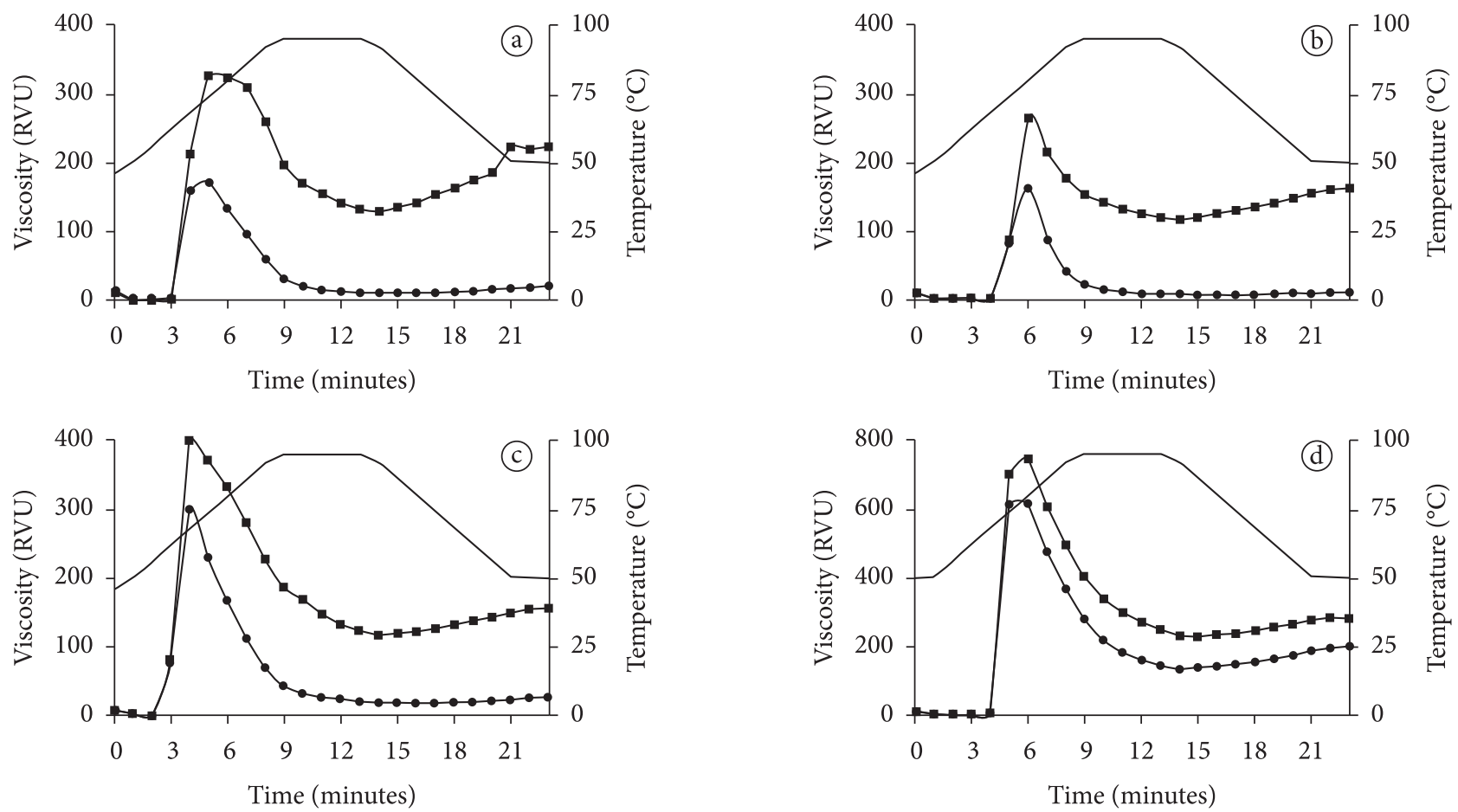

Native starch $\longrightarrow$ Hydrolyzed starch

Figure 5. Viscosity pattern of native and hydrolyzed starches a) cassava; b) sweet potato; c) Peruvian carrot; and d) potato.

Table 5. Thermal properties * of native and hydrolyzed starches.

\begin{tabular}{lcccc}
\hline \multicolumn{1}{c}{ Starch } & $\mathrm{T}_{\mathrm{o}}\left({ }^{\circ} \mathrm{C}\right)$ & $\mathrm{T}_{\mathrm{p}}\left({ }^{\circ} \mathrm{C}\right)$ & $\mathrm{T}_{\mathrm{c}}\left({ }^{\circ} \mathrm{C}\right)$ & $\Delta \mathrm{H}\left(\mathrm{J} \cdot \mathrm{g}^{-1}\right)$ \\
\hline Native cassava & $58.54^{\mathrm{c}}$ & $63.01^{\mathrm{c}}$ & $68.14^{\mathrm{c}}$ & $11.5^{\mathrm{b}}$ \\
Hydrolized cassava & $58.24^{\mathrm{cd}}$ & $62.40^{\mathrm{d}}$ & $67.50^{\mathrm{c}}$ & $11.9^{\mathrm{b}}$ \\
Native sweet potato & $67.49^{\mathrm{a}}$ & $71.70^{\mathrm{a}}$ & $75.29^{\mathrm{a}}$ & $12.3^{\mathrm{b}}$ \\
Hydrolized sweet potato & $67.73^{\mathrm{a}}$ & $71.75^{\mathrm{a}}$ & $75.41^{\mathrm{a}}$ & $11.7^{\mathrm{b}}$ \\
Native Peruvian carrot & $57.02^{\mathrm{e}}$ & $60.30^{\mathrm{e}}$ & $63.33^{\mathrm{d}}$ & $16.5^{\mathrm{a}}$ \\
Hydrolized peruvian carrot & $57.37^{\mathrm{de}}$ & $60.56^{\mathrm{e}}$ & $63.52^{\mathrm{d}}$ & $16.7^{\mathrm{a}}$ \\
Native potato & $64.18^{\mathrm{b}}$ & $67.44^{\mathrm{b}}$ & $73.11^{\mathrm{b}}$ & $15.7^{\mathrm{a}}$ \\
Hydrolized potato & $64.06^{\mathrm{b}}$ & $67.18^{\mathrm{b}}$ & $73.60^{\mathrm{b}}$ & $15.8^{\mathrm{a}}$ \\
\hline
\end{tabular}

${ }^{*} \mathrm{~T} T, \mathrm{~T}$ : onset, peak, and conclusion temperatures, respectively; $\Delta \mathrm{H}$ : enthalpy change; and "The data represent average of three replicates. Values followed by the same letter in the same column are not significantly different $(P<0.05)$.

\section{Conclusion}

Starches from different botanic sources behave differently towards enzymatic action because of their distinct structural characteristics. The cassava starch was the most susceptible to a-amylase hydrolysis followed by sweet potato and Peruvian carrot starches. The Potato starch was the most resistant to the enzyme. For the three first starches, hydrolysis occurred in the amorphous and crystalline areas of the starch granules. There was exocorrosion of the granule surface for all starches and the Peruvian carrot starch also showed granules with some degradation of its internal part. The extension of hydrolysis on the starches, except for the potato starch, was enough to modify some physicochemical characteristics of the starches such as pasting viscosity and intrinsic viscosity, but it did not modify their thermal properties.

\section{Rereferences}

AMERICAN ASSOCIATION OF CEREAL CHEMISTS - AACC. Approved methods of the american association of cereal chemists. 7. ed. Saint Paul: AACC, 2000.

COLONNA, P.; BULÉON, A.; LEMANE, F. Action of bacillus subtilis $\alpha$-amylase on native wheat starch. Biotechnology and Bioengineering, v. 31, n. 9, p. 895-904, 1988.

COTTRELL, J. E. et al. Properties of potato starch: effects of genotype and growing conditions. Phytochemistry, v. 40, n. 4, p. 1057-1064, 1995.

FRANCO, C. M. L. et al. Structural and functional characteristics of selected soft wheat starches. Cereal Chemistry, v. 79, n. 2, p. 243-248, 2002.

FRANCO, C. M. L.; CIACCO, C. F. Factors that affect the enzymatic degradation of natural starch granules: effect of size of the granules. Starch, v. 44, n. 11, p. 422-426, 1992.

FRANCO, C. M. L.; CIACCO, C. F.; TAVARES, D. Q. Studies on the susceptibility of granular cassava and corn starches to enzymatic attack: part 2 study of the granular structure of starch. Starch, v. 40, n. 1, p. 29-32, 1988.

FRANCO, C. M. L.; CIACCO, C. F.; TAVARES, D. Q.; The structure of waxy corn starch: effect of granule size. Starch, v. 50, n. 5, p. 193-198, 1998.

GALLANT, D.; MERCIER, C.; GUILBOT, A. Electron microscopy of starch granules modified by bacterial $\alpha$-amylase. Cereal Chemistry,v. 49, n. 3, p. 354-365, 1972. 
GANGA, Z. N.; CORKE, H. Physical properties of starch of Asianadapted potato varieties. Journal of Science and Food Agriculture, v. 79, n. 12, p. 1642-1646, 1999.

GÉRARD, C. et al. Amylose determination in genetically modified starches. Carbohydrate Polymers, v. 44, n. 1, p. 19-27, 2001.

HOOVER, R. Composition, molecular structure, and physicochemical properties of tuber and root starches: a review. Carbohydrate Polymers, v. 45, n. 3, p. 253-267, 2001.

HOOVER, R.; ZHOU, Y. In vitro and in vivo hydrolysis of starches by $\alpha$-amylase and resistant starch formation in legumes - a review. Carbohydrate Polymers, v. 54, n. 4, p. 401-417, 2003.

JANE, J. Current understanding on starch granule structure. Journal of Applied Glycoscience, v. 53, n. 3, p. 205-213, 2006.

JANE, J. et al. Effects of amylopectin branch length and amylose content on the gelatinization and pasting properties of starch. Cereal Chemistry, v. 76, n. 5, p. 629-637, 1999.

KASEMSUWAN, T. et al. Characterization of the dominant mutant amylose-extender (Ae1-5180) maize starch. Cereal Chemistry, v. 72, n. 5, p. 457-464, 1995.

LANSKY, S.; KOOI, M.; SCHOCH, T. J. Properties of the fractions and linear sub fraction from various starches. Journal of the American Chemical Society, v. 71, n. 12, p. 4066-4075, 1949.

LAURO, M. et al. Alpha-amylolysis of large barley starch granules. Cereal Chemistry,v. 76, n. 6, p. 925-930, 1999.

LEACH, H. W. Determination of intrinsic viscosity of starches. Cereal Chemistry, v. 40, n. 6, p. 593-600, 1963.

LEACH, H. W.; SCHOCH, T. J. Structure of the starch granule II: action of various amylases on granular starches. Cereal Chemistry, v. 38, n. 1, p. 34-46, 1961.

LI, J. H. Starch from hull-less barley: V. in-vitro susceptibility of waxy, normal, and high-amylose starches towards hydrolysis by alphaamylases and amyloglucosidase. Food Chemistry, v. 84, n. 4, p. 621-632, 2004.

LINDEBOOM, N.; CHANG, P. R.; TYLER, R. T. Analytical, biochemical and physicochemical aspects of starch granule size, with emphasis on small granule starches: a review. Starch, v. 56, n. 3-4, p. 89-99, 2004.

MCPHERSON, A. E.; JANE, J. Comparison of waxy potato with other root and tuber starches. Carbohydrate Polymers, v. 40, n. 1, p. 57-70, 1999.

MOORTHY, S. N. Tuber crop starches. 2. ed. Thiruvananthapuram: Central Tuber Crops Research Institute, 2001.

NODA, T. et al. The physicochemical properties of partially digested starch from sprouted wheat grain. Carbohydrate Polymers, v. 56, n. 3, p. 271-277, 2004.

OATES, C. G. Towards an understanding of starch granule structure and hydrolysis. Trends in Food Science and Technology, v. 8, n. 11, p. 375-382, 1997.
PERONI, F. H. G.; ROCHA, T. S.; FRANCO, C. M. L. Some structural and physicochemical characteristics of tuber and root starches. Food Science and Technology International, v. 12, n. 6, p. 505-513, 2006.

RICKARD, J. E.; ASAOKA, M.; BLANSHARD, J. M. V. The physicochemical properties of cassava starch. Tropical Science, v. 31, n. 2, p. 189-207, 1991.

ROCHA, T. S.; DEMIATE, I. M.; FRANCO, C. M. L. Características estruturais e físico-químicas de amidos de mandioquinha-salsa (Arracacia xanthorriza). Ciência e Tecnologia de Alimentos, v. 28, n. 3, p. 620-628, 2008.

SANTACRUZ, S. et al. Three underutilized sources of starch from the Andean region in Ecuador: physicochemical characterization. Carbohydrate Polymers, v. 49, n. 1, p. 63-70, 2003.

SOMOGYI, M. New reagent for the determination of sugars. The Journal of Biological Chemistry, v. 160, n. 1, p. 61-68, 1945.

SRICHUWONG, S. et al.. Starches from different botanical sources I: contribution of amylopectin fine structure to thermal properties and enzyme digestibility. Carbohydrate Polymers, v. 60, n. 4, p. 529-538, 2005.

TAKEDA, Y.; HIZUKURI, S. Structure of branched molecules of amylose of various origins. and molar fraction of branched and unbranched molecules. Carbohydrate Research, v.165, n. 1, p. 139-145, 1987.

TESTER, R. F.; QI, X.; KARKALAS, J. Hydrolysis of native starches with amylases. Animal Feed Science and Technology, v. 130, n. 1-2, p. 39-54, 2006.

WHISTLER, R. L.; BEMILLER, J. N. Carbohydrate Chemistry for Food Scientists, Saint Paul: Eagan Press, 1997.

YAMADA, T. et al. Components of the porous maize starch granule prepared by amylase treatment. Starch, v. 47, n. 9, p. 358-361, 1995.

YONEMOTO, P. G.; CALORI-DOMINGUES, M. A.; FRANCO, C. M. L. Efeito do tamanho dos grânulos nas características estruturais e físico-químicas do amido de trigo. Ciência e Tecnologia de Alimentos, v. 27, n. 4, p. 761-771, 2007.

YOU, S.; IZYDORCZYK, M. S. Molecular characteristics of barley starches with variable amylose content. Carbohydrate Polymers, v. 49, n. 1, p. 33-42, 2002.

ZHANG, T.; OATES C. G. Relationship between alpha-amylase degradation and physico-chemical properties of sweet potato starches. Food Chemistry, v. 65, n. 2, p. 157-163, 1999.

ZHOU, Y.; HOOVER, R.; LIU, Q.; Relationship between $\alpha$-amylase degradation and the structure and physicochemical properties of legume starches. Carbohydrate Polymers, v. 57, n. 3, p. 299-317, 2004. 